\title{
EFEKTIFITAS PEMBENTUKAN PERADILAN KHUSUS PEMILU DALAM PEMBANGUNAN HUKUM NASIONAL PADA PILKADA TAHUN 2020 DI ERA COVID 19 DI INDONESIA
}

\author{
${ }^{1}$ Muhammad A. Rauf \\ ${ }^{2}$ Ali Ismail Shaleh \\ ${ }^{1}$ Fakultas Hukum Universitas Riau, Email: muhammad.arauf@lecturer.unri.ac.id \\ ${ }^{2}$ Fakultas Hukum Universitas Muhammadiyah Riau, Email: aliismailshaleh@gmail.com
}

\begin{abstract}
Abstrak
Pembangunan hukum Nasional ditandai dengan berbagai kebijakan yang salah satu trendnya yaitu membangun sistem demokrasi dalam bidang Pemilihan Umum. Pemilihan Umum merupakan aktualisasi nyata dari demokrasi. Di Indonesia, pengaturan yang berkaitan mengenai Pemilihan Umum seringkali berubah-ubah demi mencari sistem penyelenggaraan Pemilihan Umum yang ideal, serta sesuai dengan keinginan politisi dan pembuat undangundang. kewenangan untuk menyelesaikan permasalahan terkait Pemilihan Umum, setidaknya dapat dikategorisasi enam jenis perkara. Perkara-perkara tersebut meliputi administratif Pemilihan Umum, proses penyelenggaraan Pemilihan Umum, perselisihan hasil Pemilihan Umum, atas tindak pidana Pemilihan Umum, kode etik penyelenggara Pemilihan Umum, dan perkara lainnya yang berkaitan dengan Pemilihan Umum. Dalam melakukan penelitian ini, tipe penelitian yang digunakan adalah penelitian hukum (legal research) yaitu suatu proses untuk menemukan aturan hukum, prinsip-prinsip hukum maupun doktrin-doktrin hukum agar dapat menjawab permasalahan hukum yang sedang dihadapi. Pendekatan yang digunakan dalam penelitian ini yaitu, pendekatan perundang-undangan adalah pendekatan dengan menggunakan legislasi dan regulasi yang berkaitan dengan isu hukum yang sedang dibahas.11 Dengan pendekataan ini maka dapat dilakukan dengan menelaah aturan hukum yang ada yakni Undang-Undang Dasar Tahun 1945 sebagai dasar tertinggi sumber hukum dan dikaitkan dengan aturan-aturan yang ada dibawahnya untuk menjawab rumusan masalah.
\end{abstract}

Kata kunci : Peradilan khusus, Pemilu, Indonesia, Covid-19

\section{PENDAHULUAN}

Pembangunan hukum Nasional ditandai dengan berbagai kebijakan yang salah satu trendnya yaitu membangun sistem demokrasi dalam bidang Pemilihan Umum.

Pemilihan Umum merupakan aktualisasi nyata dari demokrasi. Maka sudah sepatutnya Pemilihan Umum diselenggarakan melalui mekanisme yang jujur dan adil (Free and Fair 
Elections) serta diminimalisasi dari tindakan pelanggaran yang dapat menghambat proses untuk mencapai tujuan dari Pemilihan Umum. ${ }^{1}$

Di Indonesia, pengaturan yang berkaitan mengenai Pemilihan Umum seringkali berubah-ubah demi mencari sistem penyelenggaraan Pemilihan Umum yang ideal, serta sesuai dengan keinginan politisi dan pembuat undang-undang. ${ }^{2}$ Perubahan tersebut juga disesuaikan dengan dinamika masyarakat dan masukan dari akademisi terutama mengenai evaluasi pelaksanaan Pemilihan Umum di Indonesia. Saat ini, undang-undang yang berlaku mengenai Pemilihan Umum adalah UndangUndang Nomor 7 Tahun 2017 tentang Pemilihan Umum yang merupakan derivasi dari UUD NRI 1945 Pasal 22E ayat (1) sampai ayat (6). yang pada intinya mengamanahkan bahwa pelaksanaan Pemilihan Umum diselenggarakan secara langsung, umum, bebas, rahasia, jujur dan adil untuk memilih Presiden dan Wakil Presiden, anggota DPR, anggota DPD, dan anggota DPRD.

Dalam fakta empirisnya Undang-Undang Nomor 7 Tahun 2017 tentang Pemilihan Umum yang berlaku saat ini tersebut membawa perubahan signifikan bagi sistem penyelenggaraan Pemilihan Umum di Indonesia terutama dalam sistem penyelesaian sengketa.

Ide dan gagasan perlunya dibentuk lembaga khusus yang berfungsi menyelesaikan sengketa Pemilu telah mendapat legitimasi melalui Putusan MK Nomor 97/PUU.XI/2013 yang mengamanatkan pembentukan badan Peradilan Khusus Pemilihan Kepala Daerah untuk memecahkan berbagai permasalahan dan problematika yang dihadapi manakala prosedur dan mekanisme penyelesaian sengketa Pemilu belum dapat

\footnotetext{
${ }^{1}$ Widianingsih, Yuliani. "Demokrasi dan PEMILU di Indonesia: Suatu Tinjauan dari Aspek Sejarah dan Sosiologi Politik", Jurnal Signal, Vol.5, No.2, 2017, p.

2 Pardede, Marulak, "Implikasi Sistem Pemilihan Umum Indonesia", Jurnal Rechtvinding, Vol.3, No.1, April 2014, p.97.
} 
memberikan kepastian hukum. Bahkan demi membangun suatu sistem penegakkan hukum pemilu yang efektif, akuntabel dan solutif dalam masa pandemic covid 19 maka gagasan Penyelesaian Sengketa Pemilu melalui Badan Peradilan Khusus Pemilu sangat relevan untuk dikembangkan.

kewenangan untuk menyelesaikan permasalahan terkait Pemilihan Umum, setidaknya dapat dikategorisasi enam jenis perkara. Perkara-perkara tersebut meliputi administratif Pemilihan Umum, proses penyelenggaraan Pemilihan Umum, perselisihan hasil Pemilihan Umum, atas tindak pidana Pemilihan Umum, kode etik penyelenggara Pemilihan Umum, dan perkara lainnya yang berkaitan dengan Pemilihan Umum. ${ }^{3}$

Di satu sisi, penambahan suatu peradilan baru dapat mengakibatkan sistem penyelesaian sengketa Pemilihan Umum semakin elusif. Namun di sisi lain, pembentukan badan Peradilan Khusus tersebut juga dapat dimanfaatkan sebagai momentum yang tepat untuk memicu unifikasi lembaga yudisial yang khusus menangani perkara Pemilihan Umum secara holistik. ${ }^{4}$ Berdasarkan pengamatan Penulis di atas makan dalam artikel ini akan dikaji bagaimanakah Efektifitas Pembentukan Peradilan khususs Pemilu dalam Pembangunan Hukum Nasional pada Pilkada tahun 2020 di Era Covid 19 di Indonesia ?

\section{METODE PENELITIAN}

Dalam melakukan penelitian ini, tipe penelitian yang digunakan adalah penelitian hukum (legal research) yaitu suatu proses untuk menemukan aturan hukum, prinsip-prinsip hukum maupun doktrin-doktrin hukum agar dapat menjawab

\footnotetext{
${ }^{3}$ Refly Harun, 2016, PEMILU Konstitusional: Desain Penyelesaian Sengketa PEMILU Kini dan ke Depan, Penerbit Rajawali Pers, Jakarta, p.6.

${ }^{4}$ Nurul Ula Ulya, Evaluasi Yuridis Sistem Penyelesaian Sengketa Pemilihan Umum Dan Ius Constituendum Peradilan Khusus Pemilihan Umum. Jurnal JUSTITIA ET PAX, Volume 35 Nomor 2 tahin 2019, p. 155
} 
permasalahan hukum yang sedang dihadapi. ${ }^{5}$ Pendekatan yang digunakan dalam penelitian ini yaitu, pendekatan perundang-undangan adalah pendekatan dengan menggunakan legislasi dan regulasi yang berkaitan dengan isu hukum yang sedang dibahas.11 Dengan pendekataan ini maka dapat dilakukan dengan menelaah aturan hukum yang ada yakni Undang-Undang Dasar Tahun 1945 sebagai dasar tertinggi sumber hukum dan dikaitkan dengan aturan-aturan yang ada dibawahnya untuk menjawab rumusan masalah.

\section{HASIL DAN PEMBAHASAN}

Pilkada merupakan pemilihan yang di laksanakan di setiap provinsi maupun kabupaten/kota yang tersebar di 32 provinsi di Indonesia ${ }^{6}$ Peradilan Khusus Pemilu pilkada adalah Peradilan yang akan di bentuk untuk menangani sengketa pemilu yang bersifat independen dan final. ${ }^{7}$ hal tersebut bersifat urgensi dikarenakan pendemi yang berlangsung di Indonesia, maka perlu adanya peradilan khusus untuk mengadili setiap sengketa pemilu di Indonesia agar tercapainya kepastian hukum bagi masyakat Indonesia, Pemilukada pada Tahun 2020 akan melibatkan para 3 sistem hukum, yaitu Subtansi hukum dalam hal ini KPUD dan BAWASLU, serta MK lalu Struktur hukum yaitu, Peraturan-peraturan yang mengatur mengenai pilkada dan Budaya hukum yaitu, Masyarakat sebagai partisipan pemilu. ${ }^{8}$ Pada prinsipnya peradilan khusus pemilu untuk mempermudah masyarakat untuk berpartisipasi pada pemilu 2020, diakibatkan Pandemi covid-19 maka urgensi pembentukan

\footnotetext{
${ }^{5}$ Peter Mahmud Marzuki, Penelitian Hukum (Edisi Revisi) (Jakarta: Kencana Prenada Media Group, 2005), p. 29.

${ }^{6}$ A. I., Shaleh \& Raihana,(2021) Efektivitas Partisipasi Pemilih Pemula Pada Pemilihan Kepala Daerah Tahun 2020 Pada Era COVID-19 di Indonesia, Jurnal Al-Azhar Seri Ilmu Sosial, Vol. 02, No.01 P. 4

7 Putra \& Pradika, (2020) Lembaga Penyelesaian Sengketa Pemilu yang Ideal di Indonesia, Diversi Jurnal Hukum, Vol. 6 No.01, Pp. 75-76

${ }^{8}$ Friedman, L.M.,(2015) Sistem Hukum Persfektif Ilmu Sosial, Nusa Media, hlm. 27
} 
peradilan khusus pemilu dewasa ini untuk menyongsong pembahuran system peradilan di bidang pemilu pada khususnya.

\section{A. Urgensi Pembentukan Peradilan Khusus Pemilu Pada Pilkada Tahun 2020 di masa}

\section{Covid-19 di Indonesia}

Terpusatnya sebuah peradilan di Mahkamah Konstitusi (MK) mengakibatkan terjadinya penumpukan gugatan dan penundaan Putusan hal tersebut menyebabkan tidak efektifnya MK dalam menjalankan putusan yang bersifat final, menurut UndangUndang 48 Tahun 2009 tentang Kekuasaan Kehakiman mengatur tentang pengadilan yang bersifat khusus dimana kewenangannya untuk memeriksa, mengadili dan memutuskan sebuah perkara. Sebagaimana pada Pasal 01 angka 8 menyebutkan :

"Pengadilan Khusus adalah pengadilan yang mempunyai kewenangan untuk memeriksa, mengadili, dan memutus perkara tertentu yang hanya dapat di bentuk dalam salah satu lingkungan badan peradilan yang berada di bawah Mahkamah Agung yang diatur dalam undang-undang”.

Pengadilan Khusus pada umumnya terbagi menjadi 2 yaitu, pengadilan yang melaksanakan kegiatan karena hukum yang bersifat materiil dan pengadilan yang terkhusus pada subyek yang terlibat. Pengadilan khusus materiil tersebut diantaranya, pengadilan ekonomi, pengadilan niaga, pengadilan HAM, pengadilan pajak dan pengadilan perikanan. Selanjutnya pada pengadilan khusus pada subyek yang terlibat mencankupinya misalkan pada perkara pidana ekonomi maka pengadilan ekonomi yang menaunginya lalu perkara kepailitan maka di khususkan pada pengadilan niaga. ${ }^{9}$

\footnotetext{
${ }^{9}$ Rois, I dan Herawati, R., (2018) Urgensi Pembentukan Peradilan Khusus Pemilu dalam rangka Mewujudkan Integritas Pemilu, Jurnal Magister Ilmu Hukum Udayana, Vol. 07, No. 02, P. 272.
} 
Program Studi Ilmu Hukum Universitas Putera Batam

Jika melihat kondisi Pilkada Tahun 2020 yang di laksanakan pada masa pandemi Covid-19 dengan meingkatnya kasus di Indonesia. Urgensi di laksanakan pembagian kewenangan dalam mengadili sengketa pilkada agar tidak terbebaninya pemerintah khususnya MK dalam memutuskan setiap gugatan yang masuk dan dapat mengadili secara transparansi dan akuntabel, hal tersebut dapat di lihat pada data hasil partisipasi pemilih pada pilkada Tahun 2020 sebagai berikut:

NO Gubernur/Wakil Walikota/Wakil Walikota $\quad$ Bupati/Wakil Bupati

Gubernur

1. 69, 67 Persen 69, 04 Persen 77, 52 Persen

Total Nasional $\quad=\mathbf{7 6 , 0 9}$ Persen

Sumber : KPU RI

Dari data di atas dapat di lihat bahwa partisipasi masyarakat tergolong tinggi dan mengalami peningkatan dari tahun 2015 yaitu 69,06 persen maka perlu adanya perlindungan suara bagi para pemilih nasional pada pilkada tahun 2020 dewasa ini agar terjaminnya pemilu yang berintegritas serta peradilan pemilu yang bersih dan transparan.

\section{B. Hambatan dan Solusi bagi KPU, BAWASLU, dan MK dalam penyelesaian sengketa Pilkada pada tahun 2020}

Pada Putusan MK No.97/PUU-XI/2013 tentang pengujian undang-undang No. 12 Tahun 2008 tentang perubahan kedua atas undang-undang No. 32 Tahun 2004 Tentang Pemerintah Daerah dan Undang-undang No. 48 Tahun 2009 tentang Kekuasaan Kehakiman terhadap UUD NRI 1945, Putusan MK menyebutkan "berdasarkan amanat pada BAB VIIB tentang pemilihan umum, pasal 22E ayat (2) UUD NRI Tahun 1945 
dikatakan bahwa pemilihan umum di selenggarakan untuk memilih Anggota Dewan Perwakilan Rakyat, Dewan Perwakilan Daerah, Presiden dan Wakil Presiden dan Dewan Perwakilan Rakyat Daerah. Dalam hal ini Pemilihan kepala daerah tidak di atur di dalam konstitusi, oleh sebab itu maka pemilihan kepala daerah pada tahun 2020 ini bersifat khusus jika di tinjau dari putusan MK tersebut.

Pada saat ini terdapat 3 lembaga yang menjadi yang menaungi terhadap pilkada Tahun 2020 Yaitu, MK, KPU dan BAWASLU dan setiap lembaga memiliki tata cara Khusus dalam menangani sengketa maupun pelanggaran pilkada, Pada pikada 2020 terdapat beberapa permohonan dan perkara yaitu sebagai berikut,

\begin{tabular}{lcc}
\hline No & Permohonan & Perkara \\
1 & Gubernur $=8$ & Gubernur $=8$ \\
2 & Bupati $=131$ & Bupati $=128$ \\
3 & Walikota $=15$ & Walikota $=14$ \\
Total & 154 & 150 \\
\hline
\end{tabular}

Dari data di atas proses terhadap sengketa pilkada masih berjalan hingga saat ini sehingga membutuhkan waktu yang lama juga dalam memutuskan sebuah satu gugatan yang bersifat final.

Jika bawaslu dan KPU sering terjadi tumpang tindih regulasi di daerah diakibatkan oleh berbagai kebiijakan KPUD dan BAWASLU dalam merekap segala persyaratan maupun pelanggaran para peserta pilkada di daerah. Diantaranya pelanggaran etik dan pelanggaran secara administrasi, untuk menghindari permasalahan dan kesenjangan tersebut, solusi yang dihadirkan harus menentukan kewenangan dan 


\section{Program Studi Ilmu Hukum Universitas Putera Batam}

relevansi peradilan khusus pilkada maupun pemilu pada tahun 2024 mendatang, dengan mekanisme hukum dan payung hukum yang jelas. Hal tersebut sebagaimana di sebutkan pada pasal 467 ayat (4) menyebutkan bahwa " permohonan penyelesaian sengketa proses pemilu sebagaimana di maksud dalam ayat (2) di sampingkan paling lama 3 hari sejak tanggal penetapan keputusan KPU, KPU Provinsi, dan/atau KPU Kabupaten/Kota yang menjadi sebab sengketa."

Solusi yang di hadirkan penulis agar pemerintah dapat menetapkan peradilan khusus pemilu maupun pilkada agar KPU focus dalam penyeleksian calon kepala daerah dan lembaga peradilan yang akan mengadili setiap perkara pidana pemilu dan kode etik para calon kepala daerah.

\section{PENUTUP}

\subsection{Simpulan}

Pembentukan sebuah peradilan khusus dalam menghadapi sengketa pilkada tahun 2020 menjadi suatu keniscayaan dan dipandang sebagai sesuatu yang sangat urgen untuk menjamin kepastian hukum dan menghindari tumpang tindih regulasi kewenangan baik di Tingkat Mahkamah Konstitusi (MK), KPU dan Bawaslu.

\subsection{Saran}

Untuk itu Solusi yang dihadirkan harus menentukan kewenangan dan relevansi peradilan khusus pilkada maupun pemilu pada tahun 2024 mendatang, dengan mekanisme hukum dan payung hukum yang jelas agar proses penegakkan hukum Pemilu dapat berjalan dengan efektif dan menjadi solusi dalam penyederhanaan proses penyelesaian sengketa pemilu. 


\section{DAFTAR PUSTAKA}

Ali, M. Mahrus, dkk., 2011, Tafsir Konstitusional Pelanggaran PEMILUKADA yang Bersifat Sistematis, Terstruktur dan Masif, Penerbit Pusat Penelitian dan Pengkajian Kepaniteraan dan Sekretariat Jenderal Mahkamah Konstitusi Republik Indonesia, Jakarta

Refly Harun, 2016, PEMILU Konstitusional: Desain Penyelesaian Sengketa PEMILU Kini dan ke Depan, Penerbit Rajawali Pers, Jakarta

Peter Mahmud Marzuki, 2005, Penelitian Hukum (Edisi Revisi) (Jakarta: Kencana Prenada Media Group.

Friedman, L.M.,(2015) Sistem Hukum Persfektif Ilmu Sosial, Nusa Media

\section{Jurnal}

I., Shaleh \& Raihana,(2021) Efektivitas Partisipasi Pemilih Pemula Pada Pemilihan Kepala Daerah Tahun 2020 Pada Era COVID-19 di Indonesia, Jurnal Al-Azhar Seri Ilmu Sosial, Vol. 02, No.01

Putra \& Pradika, (2020) Lembaga Penyelesaian Sengketa Pemilu yang Ideal di Indonesia, Diversi Jurnal Hukum, Vol. 6 No.01.

Pardede, Marulak, "Implikasi Sistem Pemilihan Umum Indonesia", Jurnal Rechtvinding, Vol.3, No.1, April 2014.

Rois, I dan Herawati, R., (2018) Urgensi Pembentukan Peradilan Khusus Pemilu dalam rangka Mewujudkan Integritas Pemilu, Jurnal Magister Ilmu Hukum Udayana, Vol. 07, No. 02

Widianingsih, Yuliani, "Demokrasi dan PEMILU di Indonesia: Suatu Tinjauan dari Aspek Sejarah dan Sosiologi Politik”, Jurnal Signal, Vol.5, No.2, 2017.

\section{Peraturan Perundang-Undangan}

Undang-Undang Dasar Negara Republik Indonesia Tahun 1945.

Undang-Undang Nomor 7 Tahun 2017 tentang Pemilihan Umum. Lembaran Negara Republik Indonesia Tahun 2017 Nomor 182. Tambahan Lembaran Negara Republik Indonesia Nomor 6109. 